Ениса Аломеровић-Хубанић

Архив Србије, Београд

94(497.11 Београд)

alomerovic_enisa@yahoo.com

069.426:39(497.11 Београд)
https://doi.org/10.18485/ai_san_o_gradu.2018.ch2

\title{
БЕОГРАД У ОСМАНСКИМ ДОКУМЕНТИМА
}

Ограничен приступ документима који упућују на поједина раздобља у развоју Београда, данас је могуће надоместити доступном грађом из Османског архива у Истанбулу, коју Архив Србије, однедавно, похрањује. Овај рад је прилог истраживању урбаног развитка Београда. Темељи се на изворима османске провенијенције који садрже чињенице од важности за проучавање његове историје и материјалног наслеђа. Истраживањем, тумачењем и објављивањем османске архивске грађе која се односи на Београд, отварамо питања од важности за интегралну слику града у специфичним историјским условима и временским периодима.

Кључне речи: културна баштина, Београд, Архив Србије, османска документа.

Културно наслеђе је од специфичне важности за укупну баштину једнога друштва, његову традицију и прошлост. Оно прожима све материјалне и нематеријалне трагове деловања једне заједнице, стварајући осећај континуитета и идентитета народа, указује на културни развој у датим историјским приликама и упућује на преплитање различитих традиција и стваралачко богатство.

Балкан је још од античког доба био место стварања и сусрета култура Истока и Запада, Рима и Византије. У Београду је вишевековна османска владавина на 
Балкану имала и непосредан утицај на формирање културне баштине.

У путописној литератури европске провенијенције Београд заузима значајно место. Захваљујући таквој врсти извора, могу се пронаћи значајни подаци о људима, друштвеним приликама и земљама овога дела Европе. Многобројне и свакако различите догађаје бележили су бројни путописци, државни посланици али и војни чиновници који су служили у Београду. Путописци се користе различитим језицима и писмима, каткад и специфичном терминологијом, па је неупитна и јединственост слике прошлости престонога града. С друге стране, субјективни приступ својствен путописцима и драгоценост података и запажања даје Београду у компаративној слици света сасвим универзално место. Њихова сведочанства доносе живе описе предела, обичаја и веровања у појединим областима, али и податке о опсадама, сукобима и борбама за надмоћ, затим о нивоу развоја језика, прехрамбеним навикама, о узгоју пољопривредних култура, па све до интерпретација свакодневног живота, користећи се притом аналогијама и класичном литературом, дајући тако преглед историјских догађаја и уводећи читаоца у шира културолошка разматрања.

Османски архивски извори пружају могућност да продубе сазнања, спознају и потврде слику некадашњег Београда. У њима се динамички преплићу документи централних власти: фермани, ${ }^{1}$ берати, ${ }^{2}$ документи виших органа власти као што су бујурулдије ${ }^{3}$

Царска, султанова заповест, декрет.

2 Указ, диплома; документ царске канцеларије којим се поставља неки званичник, додељује одликовање или посед.

3 Заповедно писмо високих власти - великих везира, беглербегова и санџакбегова који су, уз наредбени садржај, били упућени нижим органима. Високе власти су своју одлуку доносиле овом врстом писама, при чему се ипак, при сваком важнијем питању подносио извештај Царском дивану и тражена одлука. 


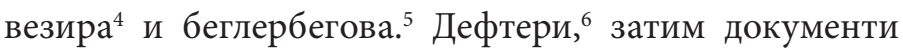
локалних органа власти и представника становништва - темесук, ${ }^{7}$ тескере, ${ }^{8}$ сенеди ${ }^{9}$ али и разни арзови, ${ }^{10}$ арзухали ${ }^{11}$ и илами, ${ }^{12}$ који представљају видове званичног обраћања локалних власти вишим органима.

Богат и разноврстан садржај града Београда, смештеног на ушћу Саве у Дунав, уписан је у саме темеље његове историје. У њој је сведочанство небројених долазака са освајачким амбицијама, боравака и останка али и одустајања и одлазака.

Војно градитељство које сажима умећа Римљана, Угара, Срба, Турака и Аустријанаца је током дугог временског распона, све до 18. века, бивало увек изнова покретачка снага развоја али и рушилаштва. Војске, народи и освајачи оставили су својеврсне градитељске и

4 Министар, члан царског дивана у Османском царству.

5 Цивилни и војни управник беглербеглука (ејалета), највеће војне и административне области у Османском царству.

6 Реч арапског порекла која носи значење свеске, дефтера, тефтера, списка, пописа, трговачке књиге. Дефтер је званична књига османске администрације и рачуноводства која има карактер пописа или обрачуна. Османско царство је још у првим годинама своје владавине образовало праксу вођења катастарских пописа. Поред катастарских вођени су порески, војнички, рачунски, платни и други пописи који су имали своју сврху.

7 Званична потврда уопште.

8 Потврда, исправа, дозвола.

9 Или сенет - потврда, признаница. Општи назив за разне документе као што су тапија (tapu senedi), потврда о преносу (tahvil senedi), рачун (makbuz senedi), дужничка признаница (deyn senedi) и слично.

10 Захтев.

11 Молба.

12 Судска одлука, службено решење. 
културне трагове кроз више временских слојева и они се, захваљујући сачуваним остацима прошлости, могу успешно реконструисати.

У средњем веку срце градова чинила је утврда. Фактори који су највише утицали на развој града јесу његов географски и топографски положај и доступност. Од средине 15. века, Београдска тврђава је била изложена нападима којима се опирала и грчевито бранила све до коначног турског освајања 1521. године. Пад под власт султана Сулејмана, носио је са собом учвршћење позиције османске војске са једне, док је са друге стране носио многа оштећења фортификације.

Како су за посед ових градских бедема вођене многобројне борбе међу којима је и напад Аустријанаца на Османлије 1688. године, под командом војводе Максимилијана Баварског, када је град и освојен, тако је и после сваког ратног разарања било потребно поново утврдити Београд са војног аспекта и повратити му онај значај који је имао пред пад у турске руке 1521. године.

Две године касније, у октобру 1690. године, Османлије поново нападају Београд и топовима га руше скоро до темеља. Свесни значаја Београдске тврђаве, који је задржавао своју стратешку важност и био средиште војске, Турци предузимају мере да се тврђава обнови, поправи и обезбеди јаком посадом, резервама хране и муницијом.

„Радови на поправци Београдске тврђаве могу се поделити у два раздобља: прво, од освојења у октобру 1690. до нове аустријске опсаде почетком августа 1693. године, и друго, од дизања те опсаде првих дана септембра исте године, па до краја рата 1699. године.“13 У

13 Веселиновић, 1974:496-509. 
првом раздобљу, радови на поправци поверени су Венецијанцу Андреји Корнару, који је из аустријске прешао у турску службу одмах након пада Београда под турском влашћу. Задужен за надзор поправке и био је активан учесник у изградњи неких нових делова у тврђави, са препознатљивим градитељским опусом, стилом и умешношћу. „Турци су под његовим руководством систематичније извели релативно веће фортификационе радове офанзивно-дефанзивне природе, а према градитељским начелима италијанске школе. "14

Бујурулдија ${ }^{15}$ великог везира упућена дефтердаpy $^{16}$ Београда, да се овом градитељу Београдске тврђаве ${ }^{17}$ због свакодневног труда и залагања на поправци тврђаве повећа надница на 500 куруша. ${ }^{18}$

Затим следи молба за издавање мулк-наме ${ }^{19}$ за промену статуса земље односно куће у којој живи мимар $^{20}$ Корнар са својом породицом. Молбом је тражено законито право власништва над земљом, односно кућом која се налазила у Горњем граду.

Турци вредно утврђују град који је преживео рушилачке походе и бројне експлозије, прикупљајући средства. На то указује хуџет ${ }^{21}$ потврђен од стране Мустафе, београдског кадије, ${ }^{22}$ за узимање новца од мухафиза ${ }^{23} \mathrm{Te}-$

14 Исто.

15 Наредба.

16 Управник, шеф финансија једног вилајета.

17 Tp. Belgrad Kalesi Mimari.

18 BOA, IE.TCT, 6-732.

19 Посебна царска дозвола. Мулк је приватно непокретно власништво.

20 Градитељ, архитекта, неимар.

21 Судско решење, дозвола, одлука.

22 Судија који је имао и знатне управне компетенције, нарочито у смислу контролисања законитости поступака војно-административних органа централне власти.

23 Заповедник града. 
мишвара, Ахмед паше. ${ }^{24}$ Затим се нижу документа која наводе трошкове за обнову везирових одаја, кухиње и амбара. За поправку ових просторија био је надлежан градски мимар Ахмед, чије је трошкове обезбеђивао и исплаћивао београдски дефтердар, ${ }^{25}$ Решид ефендија. ${ }^{26}$

У самој тврђави постојао је магацин и радионице оружја, муниције и ратног материјала. Муниција за ратне потребе и допуњавање џебхане ${ }^{27}$ у Београдској тврђави плаћена је новцем који је убиран путем босанске џизије ${ }^{28}$ из $1690 .{ }^{29}$ О овим објектима досадашња знања своје утемељење проналазила су у путописима. Тако, о њима углавном даје податке османски путописац Евлија Челеби, ${ }^{30}$ познати путник из 17. века који је провео више од четрдесет година путујући земљама Османског царства и изван његових граница.

Због свога положаја на двема великим пловним рекама, Београд је још у првим деценијама 16. века био важна геостратешка тачка у југоисточној Европи и кључна веза овог подручја са централном Европом. Велико пристаниште на Дунаву имало је чисто трговачки карактер, имајући у свом саставу и царинарску установу која се спомиње већ у збирном попису Смедеревског санџака из 1521-1523. године. ${ }^{31}$ Београдско

BOA, AE.SSÜL, II. 9-817.

Вид. нап. 15.

BOA, C.AS, 1202-53824.

Складиште муниције.

28 Један од главних државних прихода, који је трошен углавном у војне сврхе. Свака промена у висини џизије проистицала је из потреба тренутног стања у држави. Зато је проучавање џизије важно за утврђивање економских прилика одређеног времена и простора.

29 BOA, SSÜL.II, 11-1076.

30 Пуним именом тр. Evliyâ Çelebi bin Derviş Mehemmed Zillî.

31 BOA, TT.d, 135. 
пристаниште било је средиште увоза и извоза кроз које је пролазило мноштво лађа са робом а што је омогућавало наплату и убирање царине која су вршили емини. ${ }^{32}$ Одређена сазнања о економској и трговачкој динамици града, који је био значајан прометни центар, даје белешка о часној заповести у вези са узимањем царине од трговаца који су Дунавом пристигли у ово пристаниште. ${ }^{33}$

Бројни су хуџети ${ }^{34}$ београдских и других кадија ${ }^{35}$ и наиба ${ }^{36}$ који сведоче о транспорту пшенице преношене до Београда преко пристаништа у Видину, Силистри и клисуре Ђердап. Кроз документа се могу уочити да су на путу пропадале знатне количине житарица услед невремена, пада у споменуту клисуру или током дугог задржавања бродова на Дунаву, који је диктирао замрзнути Ђердап. ${ }^{37}$

О томе како је изгледао дочек страних посланика почетком 17. века најбоље сведоче рачуни о потрошњи намирница које су потрошене током боравка, проласка и одмора енглеског посланика Херберта Пеџета ${ }^{38}$ у Београду. ${ }^{39}$ Циркулисање страних чиновника кроз Београд се, у османским административним документима,

32 Емин је општи назив за најважније царинске чиновнике којима је поверавана управа, сакупљање, пописивање, чување и заштита одређених државних прихода, царинских домена и добара уопште.

33 BOA, AE.SMMD.II, 20-2177.

34 Вид. нап. 21.

35 Вид. нап. 22.

36 Кадијин помоћник.

37 BOA, İE.ADL, 6-373; İE.ADL, 3-148; İE.ADL, 2-128; İE.ADL, 2-114; İE.ADL, 2-109.

38 Енглески посланик за преговоре о миру. Током своје дипломатске активности, пролазио је кроз Београд, настављајући пут Једрена ради преговора са великим везиром.

39 BOA, İE. 3-286; İE. 3-332. 
бележило кроз разне телхисе ${ }^{40}$ па се у овом периоду издваја телхис издат Џафер паши ${ }^{41}$ београдском мухафизу, у вези са преузетим намирницама из београдског амбара како би се угостили и подмириле потребе куруцког краља Имрих Текелија ${ }^{42}$ и његове пратње, која је садржала пешадијску војску и коњанике.

Многи градови у данашњој Србији, као што су: Смедерево, Ниш, Врање, Лесковац, и утврде на ободима Дунава међу којима су: Голубац, Рам тврђава код Великог Градишта, тврђава Шабац, Петроварадин и тврђава у Кладову су имале свој стратешки значај. Београд је још у 16. веку по свом значају, лепоти и величини умногоме надмашивао околне балканске градове али и многе друге градове европског дела Османског царства. Османлије су Београд држале као центар у коме се спроводила осмишљена османска државна политика са добрим војно-административним, комуникационим, географско-стратешким, привредним и другим приликама.

Како због потребе да се прецизније одреди о ком Београду је реч, тако и ради „улепшавања стила, звучне риме, конвенционалног украса и традиционалне навике“43, у документима османске провенијенције могу се видети бројне апозиције или атрибути који га ближе одређују. Катастарске књиге представљају богату и разноврсну и веродостојну грађу за изучавање историјске

40 Папир у виду сажетка, резимеа.

41 Бујук Џафер паша (тр. Büyük Cafer Paşa) био је мухафиз Београда у периоду од 1692. до 1695. године. Један од највећих јунака свога времена, одбранио је аустријску опсаду Београда предузету 1693. године.

42 Или Имрих Токоли; мађ. Thököly/Tököly/Tökölli Imre (1657-1705). Османлије су га 1682. године поставиле за кнеза Горње Угарске јер се борио на њиховој страни против Аустрије.

43 Бајрактаревић, 1951:221. 
географије и топонимије. Због свог граничног положаја Београд добија назив Belgrad-ı Dârül-Cihad ${ }^{44}$ - подручје џихада; кућа, капија или место светог рата. Поред тога носи и следеће називе: Belgrad-ı Tuna или Tuna Belgradi ${ }^{45}$ - Дунавски Београд или Београд на Дунаву, Belgrad-ı Üngürüs ${ }^{46}$ - Мађарски Београд, ${ }^{47}$ Belgrad-ı Semendire Смедеревски Београд, Medine-i Belgrad - град Београд, Fikir Tepe - брег за размишљање, Belgrad Kale-i Bala Горњи град Београдске тврђаве, Belgrad Kale-i Zir - Доњи град Београдске тврђаве, ${ }^{48}$ Hayrul bilâd - место, град cpeћe, Fütuh-Âbâd, İrem-Âbâd, Rasinül-Bünyâd, Sengin Bünyâd, ${ }^{49}$ а јавља се у многим другим варијантама.

Током 17. и 18. века Београд је више пута окупиран од стране Аустрије и Турске. Београдска тврђава претрпела је и преко река и са копна топове свих калибара. Освајачи су, одмах након пробијања и освајања београдске територије, изграђивали и уређивали град по свом нахођењу. Сталне промене у изгледу града могу се увидети на појединим гравирама, мапама и картографским приказима али се не могу тачно хронолошки одредити.

Османска рукописна карта Београда ${ }^{50}$ која се чува у Архиву Србије, такође је важан извор за проучавање прошлости. Она је сведочанство развоја Београдске тврђаве која данас представља вредно културно наслеђе.

На карти постоји ознака за четири стране света те је тумачена по конвенционалном правилу - окрену-

44 BOA, TT.d 978, TT.d 187, TT.d 316, TT.d 517 - опширни пописи Смедеревског санџака.

45 BOA, AE.SMMD.II, 20-2177.

46 Ungürus (Engürüs) значи Мађар. Овај термин се користио да означи Мађарски ејалет.

47 BOA, AE.SAMD. II, 17-1881.

48 BOA, İE.EV, 32-3677.

49 Türk Ansiklopedisi, 1953:68-69.

50 AC, P-31/ ГK-7. 
та севером према горе. Размер на карти представљен је графички и текстуално и износи 1:200 османских зиpa. ${ }^{51} \mathrm{Ca}$ аспекта дизајна карте аутор је бојама изразио разнолику садржајност. Графички елементи на карти писани су на османском језику. ${ }^{52}$

Београдска тврђава данас поседује капије из различитих периода: Сахат капију, Зиндан, Стамбол, Пристанишну или лиман капију, Видин капију, Сава капију и друге. Поред ових, на османској карти налази се назив за још једну капију која до данашњих дана није била позната. Такозвана Циганска капија ${ }^{53}$ која је уцртана на месту који је представљао источни улаз у Доњи град код Видин капије. Претпоставке су да је она била на месту данашњег комплекса Источне капије Доњег града.

У османском феудализму, Роми су заузимали релативно значајно место. Били су укључени у разне државне службе, углавном као занатлије по тврђавама и пристаништима. Према списима француских савременика из 16. и 17. века, песмом и игром, увесељавали су посаду тврђаве. ${ }^{54}$ Могло би се рећи да назив ове капије указује на питање како места тако и улоге Рома у османском друштву. ${ }^{55}$

51 Попут аршина, зира је мера за дужину која износи $0,57417 \mathrm{~m}^{2}$ односно 4 корака.

52 На карти се налазе накнадне белешке, односно преводи неких одредница писане графитном оловком и ћириличним писмом. Претпоставља се да је неко од истраживача познавао карту и проучавао њен садржај. Такође се претпоставља да је ова карта коришћена за Ж. Шкаламерине картографске реконструкције просторног плана Београда, који је публикован у првом тому књиге Историја Београда, издате 1974. године.

53 Осм. Çingane kapısı.

54 Детаљнији опис Цигана дао је француски путописац Кикле у свом опису града Београда.

Самарџић, 1961:195.

55 Султан Сулејман је 1530. године издао специјални „Закон о Ци- 
„У саставу јерлијске посаде ${ }^{56}$ налазила се и бео-

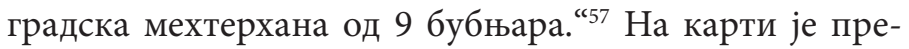
цизно уцртана мехтерхана - караула за музичаре $\mathrm{e}^{58}$ која се налазила на западном бедему Доњег града, код Диздареве Су капије односно између Бејаз табије и Султан Мустафине табије. ${ }^{59}$ Претпоставља се да је караула била намењена мехтеранима - јаничарској музици, војном оркестру који је пратио јаничарске јединице у њиховим војним походима, као и султана и друге османске угледнике у току њихових јавних наступа.

Одредница на карти Дамат Али пашиног турбета које је подигнуто 1741. или 1742. године, недалеко од некадашње султан Махмудове џамије, која је такође уцртана на карти, доводи до прецизнијег датума настанка карте чиме се указује на посебну вредност картографског извора како за реконструкцију тако и за датирање.

У турбету су сахрањена још два турска великодостојника, Селим паша који је преминуо непосредно након постављења за мухафиза ${ }^{60}$ Београдске тврђаве 1847. године, као и Хасан паша Чешмелија који је 1848. године постављен за београдског мухафиза ${ }^{61}$ на којем положају је остао све до смрти 1850. године.

Година смрти београдског мухафиза Хасан паше

ганима Румелије“, који регулише њихов правни положај. Овај Закон помаже да се боље разумеју информације које произилазе из пореских књига али и осликава стање тог периода. ВОА, A.DFE.d, 6.

56 Поред сталне посаде какви су били мустахфизи, фариси и азапи, београдски гарнизон састојао се из овог рода, који је у свом саставу имао и припаднике других оџака: јаничаре, топџије, џебеџије, барутчије, лагумџије али и неке помоћне родове.

57 Тричковић, 1972:618.

58 Осм. Maûsikî-i kara kule.

59 Данас Бастион Светог Јакова.

60 Вид. нап. 23.

61 Исто. 
Чешмелије (1850), чије је име наведено на карти, и година напуштања београдске територије од стране турске војне посаде (1867), могу представљати њене terminus ante quem non и terminus post quem non, тј. горње и доње границе датума настанка карте.

На основу целокупне анализе садржаја може се закључити да османска карта даје слику из последњих година живота оријенталног Београда.

Поред анализе османске карте, остајемо без одговора на питања као што су: ко је аутор карте, за коју сврху је рађена и ко је могао да наручи израду овако детаљне карте, са знатном ликовном и уметничком вредношћу.

Свакако да даљим истраживањем, тумачењем и објављивањем османске архивске грађе која се односи на Београд, континуитет и дисконтинуитет самога града, долазимо до могућности да отворимо питања од важности за целовиту слику града у специфичним историјским условима и периодима.

\section{Извори}

Необјављени архивски извори

Архив Србије:

AC, Р-31/ ГК-7.

Османски архив Председништва Владе - Başbakanlık Osmanlı Arşivi (BOA):

A.DFE.d

AE.SAMD. II

AE.SMMD.II

AE.SSÜL, II

İE

İE.ADL

İE.EV 
IE.TCT

C.AS

SSÜL.II

TT.d.

\section{Литература}

Agoston, Gabor и Bruce Masters. Encyclopedia of the Ottoman Empire. United States of America, 2009.

Aslantaş, Selim. „Belgrad-1 Dârü'l-Cihad”. Hacettepe Üniveritesi Türkiyat Araştırmaları Dergisi 15 (2011): 13-37.

Akbayar, Nuri. Osmanlı Yer Adları Sözlüğ̈̈, Tarih Vakfı Yurt Yayınları. İstanbul, 2001.

Бајрактаревић, Фехим. „Како су Турци звали Београд“. Историјски часопис, 3. Београд (1951-1952):209-225.

Веселиновић, Рајко. „Поново под турском влашћу, 8. 169016. 1717. године“. Васа Чубриловић (ур.). Истиорија Беоiрaga I. Београд, 1974. 496-509.

Иналџик, Халил. Османско цзарстиво Класично gоба 13001600. Београд, 2003.

Зиројевић, Олга. Србија йоg йурском влашћу 1459-1804. Београд, 2007.

Радован, Самарџић. Беоіраg и Србија у gелима франиуских савременика XVI-XVII век. Београд, 1961.

Тричковић, Радмила. „Списак мухафиза Београда од 1690. до 1789. године“. Исӣоријски часойис, XVIII. Београд (1971): 297-328.

Тричковић, Радмила. „Главна тврђава царства према Европи“. Васа Чубриловић (ур.). Исӣорија Беоіраga I. Београд, 1974.

Türk Ansiklopedisi, VI, Milli Eğitim Basımevi. Ankara, 1953.

Tulum, Mertol. Osmanlı Türkçesi Büyük El Sözlüğü. İstanbul, 2013.

Челеби, Евлија. Пуйойис - одломии о јуїословенским земљама. Сарајево, 1979.

Чубриловић, Васа. Ист̄орија Беоі̄paga I. Београд, 1974.

Ђурић-Замоло, Дивна. Беоіраg као оријенйална варош ӣog Туриима 1521-1867. Београд, 1977. 
Катић, Татјана. Турско освајање Србије 1690. іоgине. Београд, 2012.

Ferit, Devellioğlu. Osmanlıca-Türkçe Ansiklopedik Lugat. Ankara, 2013.

Шкриванић, Гавро и Глиша Елезовић. Како су Турии йосле више ойсаgа заузели Беоі̄pag. Београд, 1956. 